\title{
Stock Market Integration Among Asian Economies in a Case of India, China, and Japan
}

\author{
Pritpal Singh Bhullar \\ University Business School, Maharaja Ranjit Singh Punjab Technical University, Dabwali Rd, Lal Singh Nagar, Bathinda, Punjab 151001, India
}

\begin{tabular}{l} 
A R T I C L E I N F O \\
\hline Keywords: \\
Asian Economies, \\
Stock Indices, \\
VECM, \\
Johansen Cointegration Test, \\
E-Views \\
Kata kunci: \\
Ekonomi Asia, \\
Indeks Saham, \\
VECM, \\
Tes Kointegrasi Johansen, \\
E-Views
\end{tabular}

Corresponding author:

bhullar_pritpal36@yahoo.co.in

\section{ABS TRACT}

Globalisation has opened the door for global investors to avoid the saturation of investment opportunities in the domestic market. Latest technological advancement, accessibility to financial and global information, liberalisation and globalisation put the global market into a new investment framework. The present paper aims to examine the level of cointegration between three big Asian economic powers India, China and Japan. Twenty-years data has been analyzed by applying Johansen Cointegration, Vector Error Correction Model, and other econometric statistical tests in E-Views. The findings suggest a long-run relationship between India (BSE) and Japan Stock indices (Nikkie), but no such integration find of these two stock indices with China Stock Exchange (Shanghai).

\section{SARI PATI}

Globalisasi telah membuka pintu bagi investor global untuk menghindari kejenuhan peluang investasi di pasar domestik. Kemajuan teknologi terkini, aksesibilitas pada informasi keuangan dan global, liberalisasi dan globalisasi menempatkan pasar global ke dalam kerangka investasi baru. Makalah ini bertujuan untuk menguji tingkat Kointegrasi antara tiga kekuatan ekonomi besar Asia, India, Cina, dan Jepang. Data 20 Tahun telah dianalisis dengan menerapkan Johansen Cointegration, Vector Error Correction Model dan tes statistik ekonometrik lainnya dalam E-Views. Temuan ini menunjukkan hubungan jangka panjang antara India (BSE) dan indeks Bursa Jepang (Nikkie), tetapi tidak ada integrasi seperti ditemukan pada dua indeks saham ini dengan Bursa Efek China (Shenghai).

(ㄷ) 2019 IRJBS, All rights reserved. 


\section{INTRODUCTION}

In today's fragile global economic environment, the integration among global economies has been raised to a new level. The financial integration among global markets strengthens the flow of investment beyond the geographical boundaries across the globe. The different mechanism of investment movement and control across the nations embedded a big challenge. The interdependency among global stock markets has increased the volatility in the global investment pattern. It has significant impact upon the structure of global investment portfolio as the return from the investment depends upon the level of diversification among different global asset classes and economies. It depends upon the scale and direction of correlation in the return on investment of securities among global stock markets. If there is strong correlation among global stock markets then the investor can never reap benefit from international diversification of their portfolio. It has become mandatory for the investors to decode the level of integration among economies and their stock markets to hedge the volatility level in investment. The globalization of countries' stock indexes draw the attention of global individual and big institutional investors, policy makers, financial analysts to tackle the global volatile investment level and return. Chattopadhyay and Behera (2008) investigated a significant development in the Indian stock markets due to liberalization policies of government. Policy makers and financial analysts show their skewness towards measuring the impact

of the global events as they have significant influence on the economic growth of country. Under such global investment scenario, the integration of global stock indexes play a pivotal role at international platform. Baker et. al. (2009) observed that the accessibility to cheaper finance and underpricing assets in foreign countries open the doors for large number of investment opportunities for global investors. It helps the investors to reduce economy specific risk. Thus stock market integration has become creates numerous avenues for increasing shareholders and investors wealth. Marashdeh and Shrestha (2010) concluded in their study that the markets were integrated and diversified to reap abnormal profits. Globalisation and liberalisation gave India new global dimensions. It is very important to examine the stock market integration of India with other Asian economies after the recession and demonetisation period. The present paper is a sincere endeavour to examine the level of Cointegration among stock markets of major Asian economies (India, China and Japan). It is a sincere attempt to dive a little deeper to understand the level of interdependence and Cointegration between stock market around the globe that help the investors in making their investment decisions strategies. It aims to investigate the degree long-run relationship between Indian stock market and other Asian stock markets.

The paper is organised as thus: Section 2 exhibits the existing literature related to the theme of paper. The explanation about the research framework including statistical methods devised for data analysis is presented in Section 3. Section 4 comprises of statistical results and their interpretation. The findings and concluding remarks are covered under section 5 .

\section{Literature Review}

The following section discuses the topic based previous research studies and examine their findings from their research.

Ameer (2006) observed a significant correlation movement of Malaysia, South Korea and Thailand towards the global financial integration. Karagoz and Ergun (2010) find least causal relationship between stock market of Balkan region and Turkey. The study further examined other stock markets and documented UK stock market has more global influence as compared to other developed economies like Japn and US. Siddiqui and Seth (2010) noticed a non existence of correlation between Indian stock indexes and Shenghai stock exchange. Arouri and Nguyen 
(2010) analyzed the existence of Cointegration between gulf stock markets. The findings of study show the non significant movements among the Gulf stock markets that further signifies the bleak and insignificant relationship between gulf markets and other markets. Yi and Tan (2009) examined the degree of integration among domestic markets with global stock indices. Ibrahim (2005) conducted a study to measure the impact of financial crisis on the financial stability of a nation and find the potential global diversification opportunities to the global investors. Saha and Bhunia (2012) have found long- and short-run integration between Indian and other South Asian economies under study. Morales and Callaghan (2010) puts its weight behind the fact that the influence of US over Asian stock exchange overweighs the Japanese market. The housing bubble burst in US in 2007-2008 cause the crashing of global stock markets. Tripathi and Sethi (2010) examined the stock market data of India, UK, Japan, US and China during a period from 1998 to 2008. They devised Granger Cointegration test to analyze the data. The findings of study observed that the influence of US stock market dominate the influence of UK, Japan and China over Indian stock indexes. Hasan et al. (2008) probed the integration of Karachi stock index with global developed economies by applying Cointegration analysis. The study finds the non existence of Cointegration of Karachi stock index with stock indexes of developed economies such as USA, Canada, Italy, Australia. Sam AgyeiAmpomah (2011) examined the stock market integration in African countries. The research data for analysis was taken from 1998 to 2007. The findings of study show that African stock indexes are fragmented from global stock markets and portfolio diversification across countries. Rajwani and Mukherjee (2013) conducted a study on global stock indices during a period from January 1991 to December 2011. They found non-existence of Cointegration of Indian stock market with other markets individually and collectively. Sharma (2010) found that existence of numerous global factors like political instability, currency fluctuation risk, technological developments and dissemination of information has significant influence on the integration of domestic stock markets with other global stock markets. Batareddy et al. (2012) recommended the time factor as an integral part of Cointegration of global stock markets. They found that degree of Cointegration among stock markets may changes over time.

\section{Research Objectives}

The objective of this paper is to analyze the linkages between the Indian stock market with other Asian stock markets, namely China, and Japan.

\section{Research Framework}

The present study is completely based on the secondary (historical) data of stock markets of three Asian economic powers i.e. India, China and Japan. To study the Cointegration movement between Indian Stock index namely BSE, China stock index and Japanese stock index the monthly data of variables for 20 years from January 1999 to December 2018 was taken. To sustain the credibility of data, the normality of the data has been tested. The non - normal data has been transformed into normal data by taking log. Cointegration test, VECM Model and Granger Causality test has been applied to test the level of Cointegration among the Asian economic powers under study. E-views statistical package was applied to execute the objective of study. The following statistical test has been implemented in E-views at various stages of analysis:

\section{Augmented Dickey-Fuller (ADF) Test}

Stationarity of data is an important issue in time series analysis. To investigate the stationarity of data, Augmented Dickey- Fuller (1979) test was applied.

Null Hypothesis : Level series has unit root

Alternative hypothesis : Unit root does not exist in level series.

\section{Johansen Cointegration Test}

Cointegration between the asian stock indexes was tested by devising Johansen's Cointegration Test. It was applied to examine if long term relationship 
exist between the variables under study. If the results of Cointegration test confirm long run relationship then Vector Error Correction Model (VECM) can be applied.

\section{RESULTS AND DISCUSSIONS}

\section{Descriptive Statistics}

The descriptive summary statistics for the three Asian stock index series are presented in Table I

Table 1. Statistics Summary

\begin{tabular}{lllc}
\hline & BSE & Nikkie & Shenghai \\
\hline Mean & -0.0001 & -0.0002 & 7.7117 \\
\hline Median & -0.0051 & -0.0013 & 7.7065 \\
\hline Maximum & 0.2928 & 0.2645 & 8.6919 \\
\hline Minimum & -0.2578 & -0.1656 & 6.9667 \\
\hline Std. Dev. & 0.0916 & 0.0741 & 0.3666 \\
\hline Skewness & 0.1135 & 0.3481 & 0.0515 \\
\hline Kurtosis & 3.1652 & 3.2690 & 2.4297 \\
\hline Jarque-Bera & 0.7827 & 5.5261 & 3.3304 \\
\hline Prob. & 0.6761 & 0.630 & 0.1891 \\
\hline
\end{tabular}

Source: Authors' Own Work: Eviews Output

The descriptive statistics depicts that the indexes are positively skewed. It means they are positive towards the market return. The kurtosis for BSE and Nikkie are more than 3 whereas for Shenghai it is less than 3. The p-values of Jarque-Bera test for all the three indexes is more than 0.05 that signifies the normality of data for all three indexes.

\section{Correlation Statistics}

Table 2. Correlation Summary

\begin{tabular}{llll}
\hline $\begin{array}{l}\text { Indices } \\
\text { (Countries) }\end{array}$ & BSE & Nikkie & Shenghai \\
\hline BSE (India) & 1.000 & & \\
\hline Nikkie (Japan) & 0.4667 & 1.000 & \\
\hline Shenghai (China) & -0.008967 & 0.006450 & 1.000 \\
\hline
\end{tabular}

Source: Authors' Own Work: Eviews Output

The correlation statistics shows a positive correlation between BSE and Nikkie stock index whereas a negative correlation movement is noticed between BSE and Shenghai.

\section{Test of Stationarity}

\section{ADF Stationarity Test}

The stationary properties of data are investigated by using Augmented Dickey and Fuller (ADF) (1979) and Phillips and Perron (PP) (1988) unit root tests.

Table 3. ADF Statistics

\begin{tabular}{lll}
\hline & \multicolumn{2}{c}{ At Zero Level } \\
\hline Country & ADF Statistic & p-value \\
\hline BSE & -15.459 & 0.000 \\
\hline Shenghai & -2.178 & 0.0314 \\
\hline Nikkie & -12.186 & 0.000 \\
\hline
\end{tabular}

Source: Author's Own work

Lag length:2 (Automatic-based on SIC, maxlag=14)

The ADF statistics depicted in the above table leads to the rejection of Null hypothesis as the $p$ value is lower than 0.05 . It signifies the non existence of unit rot test in the data and shows that series is stationary.

\section{Phillips -Perron (PP) Stationarity Test}

Table 4. Philips - Perron Statistics

\begin{tabular}{lcc}
\hline \multicolumn{2}{c}{ At Zero Level } \\
\hline Country & \\
\hline BSE & -81.103 & 0.0001 \\
\hline Shenghai & -2.593 & 0.0497 \\
\hline Nikkie & -69.269 & 0.0001 \\
\hline
\end{tabular}

Source: Author's Own work

Exogenous: Constant

Bandwidth(Newey-West automatic) using Bartlett Kernel

The Philips - Perron test statistics depicted in table - IV shows that the p value is lower than 0.05 . That rejects the Null hypothesis. It signifies the non existence of unit rot test in the data and shows that series is stationary. The results of P-P test supports the results of $\mathrm{ADF}$ statistics.

\section{Cointegration Test}

\section{Johansen Cointegration Test}

To investigate the long run relationship between the stock indices, Cointegration test was applied. 
Table 5. Trace Statistics

\begin{tabular}{lllll}
\hline \multicolumn{2}{l}{ Unrestricted Cointegration rank Test (Trace) } & & \\
\hline Hypothesized No. of CE (s) & Eigen Value & Trace Statistics & 0.05 Critical Value & \multirow{2}{*}{ Prob* } \\
\hline None * & 0.502115 & 296.9672 & 29.79707 & 0.0001 \\
\hline At most $1 *$ & 0.422260 & 133.0816 & 15.49471 & 0.0001 \\
\hline At most $2 *$ & 0.017518 & 4.153221 & 3.841466 & 0.0415 \\
\hline
\end{tabular}

Table 6. Maximum Eigen Value Statistics

\begin{tabular}{lllll}
\hline \multicolumn{2}{l}{ Unrestricted Cointegration rank Test (Trace) } & & \\
\hline Hypothesized No. of CE (s) & Eigen Value & $\begin{array}{c}\text { Max Eigen } \\
\text { Statistics }\end{array}$ & 0.05 Critical Value & Prob* \\
\hline None * & 0.502115 & 163.8857 & 21.13162 & 0.0001 \\
\hline At most $1 *$ & 0.422260 & 128.9284 & 14.26460 & 0.0001 \\
\hline At most $2 *$ & 0.017518 & 4.153221 & 3.841466 & 0.0415 \\
\hline
\end{tabular}

Table 7. Granger Causality Statistics

\begin{tabular}{lccr}
\hline & obs & F - Statistics & Prob. \\
\hline NIKKIE does not Granger Cause BSE & 236 & 38.6540 & 3. E-15 \\
\hline BSE does not Granger Cause NIKKIE & & 3.80284 & 0.0237 \\
\hline & & & \\
\hline SHENGHAI does not Granger Cause BSE & 236 & 5.64509 & 0.0040 \\
\hline BSE does not Granger Cause SHENGHAI & & 0.10468 & 0.9007 \\
\hline & 236 & & 0.61567 \\
\hline SHENGHAI does not Granger Cause NIKKIE & & 1.08793 & 0.5412 \\
\hline NIKKIE does not Granger Cause SHENGHAI & & & 0.7044 \\
\hline
\end{tabular}

The trace statistics presented in table 5 indicates the existence of Cointegration in the stock indices as trace statistics values are higher than critical values. The p-values statistics support the results as p-values are less than 0.05 . It rejects the null hypothesis of no Cointegration between stock indices.

\section{Maximum Eigen Value}

The maximum Eigen statistics depicted in table 6 indicates the existence of Cointegration in the stock indices as maximum eigen statistics values are higher than critical values. The p-values statistics support the results as p-values are less than 0.05 .

\section{Granger Causality Test}

Table 7 indicate the causal relationship between BSE and Nikkie stock indices but it does not show any causal relationship between BSE and Shenghai and Shenghai and Nikkie.

\section{Vector Error Correction Model}

$\mathrm{D}(\mathrm{BSE})=\mathrm{C}(1) *(\mathrm{BSE}(-1)-0.940251873547 * \mathrm{NIKKIE}$ $(-1)+0.00366720704542 *$ SHENGHAI $(-1)$

$-0.0287465767836)+\mathrm{C}(2) * \mathrm{D}(\operatorname{BSE}(-1))+$ $\mathrm{C}(3) * \mathrm{D}(\mathrm{NIKKIE}(-1))+\mathrm{C}(4) * \mathrm{D}($ SHENGHAI(-1)) + $\mathrm{C}(5)$ 
Table 8. VECM Model Statistics

\begin{tabular}{cc}
\hline $\begin{array}{l}\text { Stock indices / } \\
\text { Countries }\end{array}$ & Cointegration Equation \\
\hline BSE & 1.0000 \\
\hline Nikkie & Coefficient -0.2974 \\
\hline & Std. Error - $(3.7666)$ \\
\hline t- statistics - [0.0789] \\
\hline Coefficient - 0.003667 \\
\hline & Std. Error - $(0.00684)$ \\
\hline c & t- statistics - $[0.53608]$ \\
\hline
\end{tabular}

The above statistics indicates the long run relationship between the stock indices. The results show a strong relationship between BSE and Nikkie as compared to BSE and Shenghai.

\section{MANAGERIAL IMPLICATIONS}

The rapid developments in current volatile global stock markets tend to pose immense heat before the potential investors to examine the global stock markets with vary degree of co-integration with other domestic markets. The results of current study intend to extend the benefits of global diversification. Furthermore, it also acts as torch bearer for the policy makers as mounting expected interdependencies among economies shed its significant effect on the performance of stock markets that may stretch the linkage of bullish and bearish effect between two global economies. India and china are the emerging economic powers whereas Japan has already established itself as developed economy giant on the globe. In such a global interlinked economic scenario, the relevance of present paper has been increased for the investors and policy makers for constructive management of their international investment portfolios.

\section{Concluding Remarks}

The results of study indicates an existence of Cointegration between BSE and Nikkie whereas no significant correlation movement between BSE and Shenghai. It signifies that BSE and Nikkie has influence over each other whereas these stock indices have no significant influence on Shenghai Stock exchanges. The results of our study oppose the results of (Rajwani and Mukherjee, 2013; Tripathi and Sethi, 2010). The reason behind these study may be due to the latest development in global economic and political scenario. These studies have been conducted around one decade before and with change in time, the behaviour and interdependence of stock indices may change.

\section{CONCLUSION}

The results of study indicates an existence of Cointegration between BSE and Nikkie whereas no significant correlation movement between BSE and Shenghai. It signifies that BSE and Nikkie has influence over each other whereas these stock indices have no significant influence on Shenghai Stock exchanges. The results of our study oppose the results of (Rajwani and Mukherjee, 2013; Tripathi and Sethi, 2010). The reason behind these study may be due to the latest development in global economic and political scenario. These studies have been conducted around one decade before and with change in time, the behaviour and interdependence of stock indices may change. 
REFERENCES

Ameer, R. (2006). Integration of the South and East Asian stock markets: how long to go?. Journal of Financial Reporting and Accounting, 1(1), 61-102.

Arouri, M.E.H. \& Nguyen, D.K. (2010). Time varying characteristics of cross market linkages with empirical application to Gulf stock markets. Managerial Finance,3(1). 67-70.

Baker M, Foley C \& Wurgler J (2009) Multinationals as Arbitraguers: the effect of stock market valuation on foreign direct investment. Review of financial studies, 22(1) 337-369

Batareddy, M., Gopalaswamy, A.K. \& Huang, C.H. (2012). The study of long-run relationships: a study on Asian emerging and developed stock markets (Japan and US). International Journal of Emerging Markets, 7(1), 31-48.

Hasan, A., Saleem, H.M.N. \& Abdullah, M.S. (2008). Long run relationship between an emerging equity market and equity markets of the developed world an empirical analysisof Karachi stock exchange. International Research Journal of Finance and Economics, 16 (1), 52-62.

Ibrahim, M.H. (2005). International linkages of stock prices: the case of Indonesia. Management Research News, 28(4), 93-115

Karagoz, K. \& Ergun, S. (2010). Stock market integration among Balkan countries. MIBES Transactions, 4(1), 49-59.

Marashdeh, H.A. \& Shrestha, M.B. (2010). Stock market integration in the GCC Countries. International Research Journal of Finance and Economics, 37, 102-114

Morales, L. and Callaghan, B.A. (2010), "The global financial crisis: world market or regional contagion effects?", paper presented at MFA (Mid-West Finance Association), Annual Meeting, Las Vegas, NV, 24-27 February

Rajwani, S. and Mukherjee (2013). Is the Indian stock market cointegrated with other Asian markets? Management Research Review, 36(9), 899-918

Saha, M. and Bhunia, A. (2012). Financial market integration of South Asian countries. Developing Country Studies, 2(1), 45-52.

S. A. Ampomah (2011). Stock market integration in Africa. Managerial Finance 37(3)

Sharma, G. (2010). Are the global stock markets inter-linked? Evidence from the literature", Global Journal of Management and Business Research, 10(1), 29-40

Siddiqui, S. \& Seth, N. (2010). Probing relations between S\&P CNX Nifty, BSE 30 and Shanghai Composite. Management Dynamics, 10(1),71-79.

Tripathi, V. \& Sethi, S. (2010). Integration of Indian stock market with major global stock Markets. Asian Journal of Business and Accounting, 3(1), 117-134.

Yi, Z. \& Tan, S.L. (2009). An empirical analysis of stock markets integration: comparison study of Singapore and Malaysia. The Singapore Economic Review, 54(2), 217-232. 